\title{
The main directions of effective management and development of the beekeeping industry
}

\author{
O.D. Djurabaev*, and J.Kh. Rashidov \\ Tashkent State University of Economics, 100003, Tashkent, Uzbekistan
}

\begin{abstract}
In the context of market economy risks, the main factor for the success of each branch of agriculture, including beekeeping, can be called the presence of effective management activities, which can be improved in accordance with changes in the external and internal market conjuncture, with the objective requirements of the production and sale of products. This article is the result of scientific research in the field of studying and improving the management system of the beekeeping industry. It is important to note that in the work, using the method of correlationregression analysis, a model was compiled that allows one to determine the dependence of the profit received from the sale of honey on the most significant cost areas. Also, the work carried out a factor analysis of the change in the volume of honey and calculated the productivity of bee colonies in agricultural organizations of the Republic of Uzbekistan.
\end{abstract}

\section{Introduction}

Special studies conducted around the world show that beekeeping plays an important role in various sectors of the economy. The importance of this industry is determined not only in the production of beekeeping products, which are necessary for mankind, but also as a means of pollination of agricultural crops. "Reports of the disappearance of bees from all over the world show that beekeeping is in danger of extinction." [1]. Accordingly, in many countries of the world, special attention is paid to improving the organizational and economic mechanisms of beekeeping management as an important condition for ensuring the efficiency and sustainability of the industry.

Currently, in various scientific centers and research institutions around the world, research is being carried out in many areas of effective beekeeping management. In particular, the formation of a beekeeping management strategy, the improvement of the basic approaches to the organizational and economic mechanisms of management, the expansion of cooperation between relatively small farms, an increase in the diversification of beekeeping products, an increase in the efficiency of management of innovative processes in these farms. [3].

The purpose of the research is to develop and improve the organizational and economic foundations for increasing the productivity of the industry and the effectiveness of management of the beekeeping industry.

\section{Research objectives:}

\footnotetext{
*Corresponding author: dloong1507@mail.ru
} 
- systematization of the theoretical foundations of the organization and management of the beekeeping industry;

- study of factors of development of the productive forces of beekeeping;

- evaluation of the efficiency of the industry and development of ways to optimize the organization of beekeeping;

- development of a mechanism for the formation of model beekeeping farms and modernized intersectoral relations in beekeeping.

\section{Research methods}

In the process of preparing the dissertation, such methods as general scientific, formallogical, specific methods of studying the situation, classification, generalization, horizontal and vertical comparison, econometric modeling, empirical research, factor analysis, forecasting were used.

\section{Research results}

Industrial and economic activity in the agricultural sector is highly dependent on the climatic conditions and biological processes of the region. Therefore, the process of managing agricultural production and its results must be viewed through the prism of the specific features of the industry. In his works A.G. Ivasenko notes that agricultural production imposes certain obligations to take into account the influence of a whole range of factors on which the effectiveness of the entire management system of enterprises in the agricultural sector depends. [2, c.215].

It is quite acceptable to consider management as an attempt to view the beekeeping market entity as a system with effective feedback, despite the influence of external and internal deflecting factors that impede the achievement of the main goal. Competent management should not only strive to ensure a balance of external and internal factors and adequately respond to emerging problems, but should predict these problems and be able to prevent them. If the beekeeping market entity does not seek to improve its activities, initially takes a passive position, then such a business will not remain effective in the long term.

In the case when the previously adopted managerial decision is insufficiently effective, unqualified or does not meet the requirements of a market economy, then a well-oiled monitoring system contributes to the establishment of this fact at an early stage of work and makes it possible to make adjustments to the action of the market entity. With an optimally adjusted monitoring system, problems can be identified in a timely manner, especially in decision-making that contains an element of risk.

Consequently, the main tool for exercising control over the implementation of management decisions in the beekeeping business is the presence of feedback. Feedback allows you to establish the outlined deviations in the course of work and to correct the solution.

An assessment of the economic efficiency of beekeeping management is impossible without an assessment of technological efficiency, the essence of which is that each bee colony of a beekeeping farm has sufficient strength to ensure high honey productivity.

In the course of applying the process approach to management, special attention is paid to the provision of resources for each process to achieve the set goal. The process approach to management opens up new opportunities for making informed management decisions in agricultural production. 
In the process of increasing the strength of the apiary and the productivity of bee colonies, not only the quantity, but also the quality of the bees grown is of great importance, which largely depends on the biological characteristics of the bee colony.

The methodology of the process approach to the management of the beekeeping economy implies the achievement of maximum values of the strength of the apiary within the specified time frame, which is ensured by a number of measures to strengthen bee colonies, as well as the use of zootechnical techniques, one of which is the annual change of old queen bees to young ones. The task of optimizing production processes in beekeeping can be considered to obtain the maximum values of the control parameter in a given time frame.

As a criterion for technological efficiency, the generalizing indicator "apiary strength" was defined, since this indicator is complex and takes into account the costs of innovative, environmental, zootechnical, technological, agrotechnical and organizational measures during the entire active life cycle of bee colonies.

Using the methodology of the process approach, in the course of the study, a model of the main and supporting business processes of the strategic development of the beekeeping economy was developed (Figure 1).

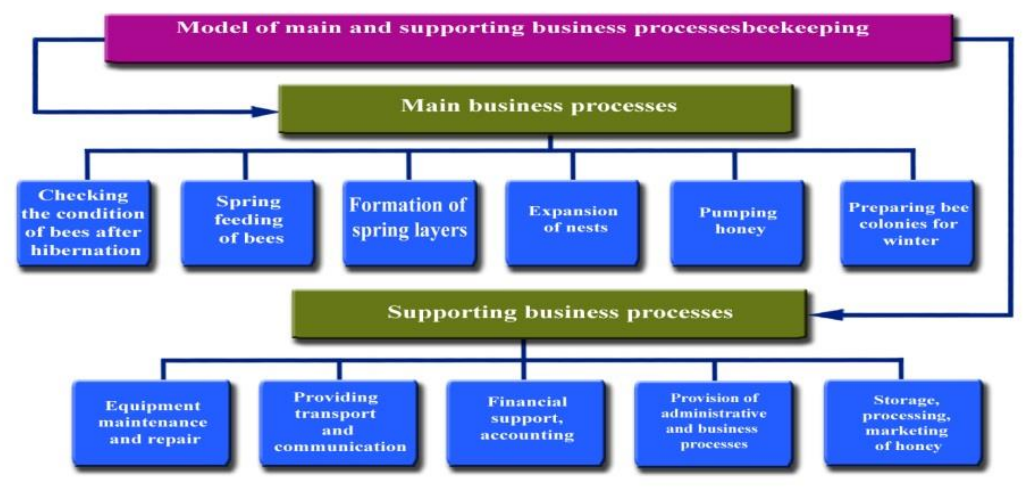

Fig. 1. Model of the main and supporting business processes of beekeeping.

The planning and management of the main technological processes is to ensure a more rational use of biological, material and labor resources of the beekeeping farm, and an increase in the strength of bee colonies on the basis of factors of intensive development and use of innovations. The application of the process approach in the management process contributes to the introduction of new resource-saving technologies that affect the main aspects of the beekeeping enterprise.

To determine the reserves for increasing the efficiency of the main business processes in beekeeping farms, it is recommended to systematically analyze the costs for all types of products.

The beekeeping industry of any form of specialization strives to reduce costs. Due to the need, it is recommended to use the cost analysis methodology by places of their origin, adapted to the beekeeping industry.

The following classification of cost centers in beekeeping farms has been proposed:

group $\mathbf{A}$ - the costs of the site, which is engaged in keeping bees. This area accounts for a significant part of the costs of the farm in beekeeping, including the costs of feed for bees, equipment and inventory for their care, and the wages of workers;

group B - divisions for storage, processing and marketing of honey. In terms of costs, these divisions are medium-cost; 
group C - subdivisions for the provision of administrative and economic processes, financial support and accounting. In terms of costs, these units are low-cost.

An analysis of costs by place of origin, carried out for each of the designated groups, helps to identify the primary reasons for the increase in costs in the beekeeping industry, take proactive actions to reduce them in the future, and also focus on managing the most costly areas.

Analyzing the most costly section A, it should be noted that among all the costs, the most significant are the costs of labor and feed for bees.

Using the method of correlation-regression analysis, during the study, a model was compiled that makes it possible to determine the dependence of the profit received from the sale of honey on the most significant costs in section A. in Table 1.

Table 1. Matrix of statistical analysis of the dependence of profit on the most significant costs in section A.

\begin{tabular}{|c|c|c|c|c|c|c|c|c|}
\hline Indicators & $2012 \mathrm{y}$ & $2013 \mathrm{y}$ & $2014 \mathrm{y}$ & $2015 \mathrm{y}$ & $2016 \mathrm{y}$ & $2017 \mathrm{y}$ & $2018 \mathrm{y}$ & $2019 \mathrm{y}$ \\
\hline $\mathrm{X} 1$ & 20100 & 25300 & 32100 & 51400 & 59700 & 77100 & 85000 & 87560 \\
\hline $\mathrm{X} 2$ & 34594 & 26487 & 31286 & 79562 & 7226 & 36872 & 16200 & 35870 \\
\hline $\begin{array}{c}\text { Effective } \\
\text { indicator } \\
\mathrm{Y}\end{array}$ & 7949 & 10878 & 10667 & 38601 & 80214 & 54614 & 26401 & 28750 \\
\hline
\end{tabular}

$\mathrm{Y}$ - gross profit from the sale of honey, thousand soums

$\mathrm{X} 1$ - labor costs, thousand soums

X2- feed costs, thousand soums

For statistical analysis, the Stata 14 program was used. The calculation results are shown in Figures 2 and 3 . All coefficients are significant at the 5\% significance level, the model is significant in general.

\begin{tabular}{l} 
Data Editor (Edit) - [556.dta] \\
\hline \hline File Edit View \\
\hline \multicolumn{4}{|c|}{ Data Tools } \\
\hline \\
\hline
\end{tabular}

Fig. 2. Initial data for calculating a model that determines the dependence of the profit received from the sale of honey on the most significant costs in section A. 


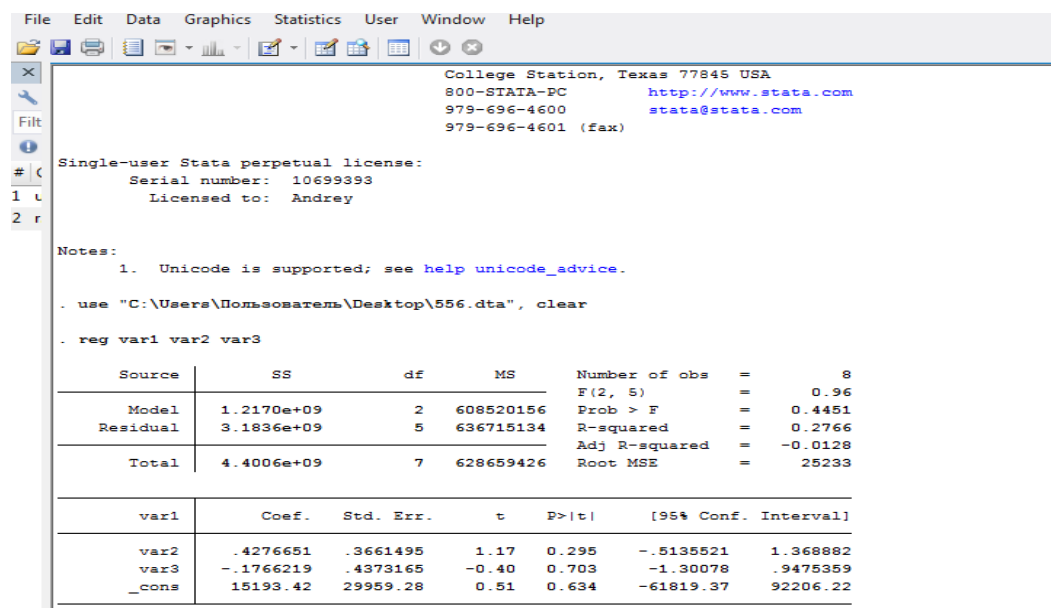

Fig. 3. Calculation of the model that determines the dependence of the profit received from the sale of honey on the most significant costs in section A

As a result of the calculations, the regression equation was obtained:

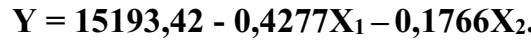

The result indicates that an increase in $\mathrm{X} 1$ by 1 thousand soums. leads to a decrease in the effective indicator $\mathrm{Y}$ by an average of 0.43 thousand soums; increase in $\mathrm{X} 2$ by 1 unit. leads to a decrease in $\mathrm{Y}$ by an average of 0.18 thousand soums. The factor $\mathrm{X} 1$ has the greatest influence on the result $\mathrm{Y}$, that is, the size of labor costs has the greatest influence on the gross profit from the sale of honey. To reduce costs in section A, it is recommended to increase productivity, mechanization and automation of labor, to minimize heavy and unproductive manual labor.

The growth of labor productivity at beekeeping enterprises is ensured by reducing the labor intensity of products, through the introduction of new technologies, mechanization and automation of production processes, various measures to improve the organization of production and labor.

An increase in the productivity of beekeeping workers is achieved by increasing the volume of collected honey and wax from each bee colony, improving the system of care and maintenance of bees. In practice, all these factors are in close interaction.

An important factor and reserve for increasing the productivity of bee workers in any form of ownership is labor motivation and strengthening of the material and technical base.

However, for the purchase of modern equipment and strengthening the material and technical base, in many beekeeping farms, there is not enough financial resources. It is possible to solve the problem of technical re-equipment of beekeeping farms by leasing equipment.

To study the trend of reducing the volume of honey, we will conduct a factor analysis of changes in the volume of honey production on the scale of the Republic of Uzbekistan.

Table 2. Initial data for factor analysis - changes in the volume of honey in the Republic of Uzbekistan

\begin{tabular}{|l|c|c|c|c|}
\hline \multicolumn{1}{|c|}{ Indicators } & $\begin{array}{c}\text { Base period } \\
2018\end{array}$ & $\begin{array}{c}\text { Reporting } \\
\text { period 2019 }\end{array}$ & $\begin{array}{c}\text { Change, } \\
\text { abs. }\end{array}$ & $\begin{array}{c}\text { Change, } \\
\text { rel. }\end{array}$ \\
\hline Production volume, tons. & 12050 & 11737 & -313 & 0,97 \\
\hline $\begin{array}{l}\text { Average number of } \\
\text { employees, people }\end{array}$ & 471 & 366 & -105 & 0,77 \\
\hline $\begin{array}{l}\text { Labor productivity, tons / } \\
\text { person }\end{array}$ & 25,58 & 32,06 & 6,48 & 1,27 \\
\hline
\end{tabular}


Absolute changes in the volume of production under the influence of changes: a) average number of employees:

$\Delta \mathrm{V}_{\mathrm{LP}}=\mathrm{P}_{0} * \Delta \mathrm{LP}=471 * 6,48=3052,08$ tons.

b) labor productivity:

$\Delta \mathrm{V}_{\mathrm{P}}=\Delta \mathrm{P} * \mathrm{LP}_{1}=-105 * 32,06=-3366,30$ tons.

c) both factors together:

$\Delta \mathrm{V}=\Delta \mathrm{V}_{\mathrm{LP}}+\Delta \mathrm{V}_{\mathrm{P}}=3052,08-3366,30=-314,22$ tons.

Consequently, on the scale of the Republic of Uzbekistan, as a result of the influence of such factors as the average number of employees in the industry and labor productivity, there is a decrease in the volume of honey produced.

Table 3. The productivity of bee colonies in agricultural organizations of the Republic of Uzbekistan

\begin{tabular}{|c|c|c|c|c|c|}
\hline Years & $\begin{array}{c}\text { Number of } \\
\text { bee colonies }\end{array}$ & $\begin{array}{c}\text { Honey } \\
\text { production, } \\
\text { tons }\end{array}$ & $\begin{array}{c}\text { Number of } \\
\text { employees, } \\
\text { people }\end{array}$ & $\begin{array}{c}\text { Productivity, } \\
\mathrm{kg}\end{array}$ & $\begin{array}{c}\text { Labor } \\
\text { productivity, } \\
\mathrm{t} / \text { person }\end{array}$ \\
\hline 2011 & 192356 & 3171,9 & 894 & 16,5 & 3,54 \\
\hline 2012 & 238644 & 3794,4 & 500 & 15,9 & 7,59 \\
\hline 2013 & 290261 & 4876,4 & 516 & 16,8 & 9,47 \\
\hline 2014 & 335002 & 7202,5 & 435 & 21,5 & 16,54 \\
\hline 2015 & 372202 & 8746,6 & 415 & 23,5 & 21,08 \\
\hline 2016 & 401463 & 10157,0 & 471 & 25,3 & 21,56 \\
\hline 2017 & 428882 & 12051,6 & 366 & 28,1 & 32,92 \\
\hline 2018 & 488211 & 11737,1 & 386 & 24,0 & 30,41 \\
\hline 2019 & 488863 & 13737,1 & 405 & 28,2 & 31,34 \\
\hline
\end{tabular}

Based on the results of the monitoring of activities and analysis of efficiency, it was revealed that a significant part of the honey produced on the farms remains unrealized, as a result of which the farms do not receive part of the profit. [5].

Difficulties with the sale of honey are associated with both high costs and disadvantages of the marketing system for honey produced at beekeeping enterprises. [4].

To improve the sale of honey, as well as other beekeeping products, of paramount importance is the formation of an organized market and market infrastructure at the global and national, as well as at the regional level, which would take over the dealer functions related to the procurement, packaging and sale of honey on a relatively mutually beneficial partnership. basis.

A number of recommendations should be considered for solving the problems of selling honey and other beekeeping products. Firstly, small-scale beekeeping farms are encouraged to cooperate to solve the problem of marketing their products and to distribute responsibilities. So, some farms can specialize in the production of beekeeping products, other farms specialize in packaging honey, wax, bee bread, third farms - to search for buyers and deliver prepackaged products to consumers.

Secondly, all farms are encouraged to participate in honey fairs held in the Republic of Uzbekistan, since these fairs promote the exchange of information, knowledge and experience of beekeepers from different regions, help to establish trade relations. 
Thirdly, it is recommended to create a website for a beekeeping farm to promote beekeeping products produced by the farm. The presence of active marketing communications allows attracting a large number of buyers of beekeeping products.

Currently, small-scale apiaries, as a rule, are available, sales only through the zero sales channel - directly to the end consumer. Smallholders do not have enough funds to organize marketing activities, create a website and other promotions. However, by partnering with a larger enterprise, the small enterprise acquires all these opportunities. For a large enterprise, the advantage of such cooperation is the purchase of high-quality honey from small farms.

Improvement of the sales system of beekeeping products will contribute to the receipt of additional profit by beekeeping farms.

Increasing the economic efficiency of beekeeping management directly depends on the methodology for identifying direct and indirect factors of the effectiveness of managerial decision-making in beekeeping [6-7].

\section{Conclusions}

The study made it possible to develop recommendations aimed at improving management and increasing the efficiency of beekeeping in the Republic of Uzbekistan.

1. The tools of management of beekeeping farms have been identified as a management system with new characteristics. The management system of beekeeping farms includes target, economic, management subsystems, as well as a subsystem of life support of the beekeeping enterprise. This system makes high demands on the quality of honey and other beekeeping products, reacts to changes in costs and expenses, takes adequate measures in the event of changes in production factors in conditions of uncertainty in the external environment.

2. The methodology of the process approach to the management of the beekeeping economy has been developed and a model has been created for the functioning of the apiary as an integral system. The criteria of the technical and economic efficiency of the apiary, contributing to its high honey productivity, are considered.

3. The most promising direction of increasing the efficiency of the beekeeping industry is the introduction of innovations concerning both the breeding and keeping of bees, and aimed at automating and mechanizing production processes, at state support for beekeepers.

The use of innovations contributes to the most rational use of biological, material and labor resources of the beekeeping economy, increasing the strength of bee colonies. The achievement of these results is facilitated by the use of motivational management methods, the introduction of new equipment and technology, the improvement of management methods, innovative biological technologies.

\section{References}

1. http://news.21.by/other-news/2019/07/19/1842722.html

2. A. G. Ivasenko, Fundamental research, 8 (2011)

3. Decree of the President of the Republic of Uzbekistan dated April 17, (2019) No. UP5708 "On measures to improve the system of public administration in the field of agriculture" https: // base.spinform.ru/show_doc.fwx?rgn=116532

4. Decree of the President of the Republic of Uzbekistan dated October 16, (2017) No. PP-3327 "On measures for the further development of the beekeeping industry in the republic" https: // www.norma.uz/uz/raznoe/ postanovlenie_prezidenta_respubliki_uzb ekistan30 
5. O. Djurabaev, Archive of Scientific Research 11 (2020)

6. O. Djurabaev Archive of scientific research 12 (2020)

7. R.R. Sultanova, M.V. Martynova, D.A. Khanov, N.P. Bunkova, Agrarian Bulletin of the Urals, 2(156), 10 (2017) 